Neuro Images

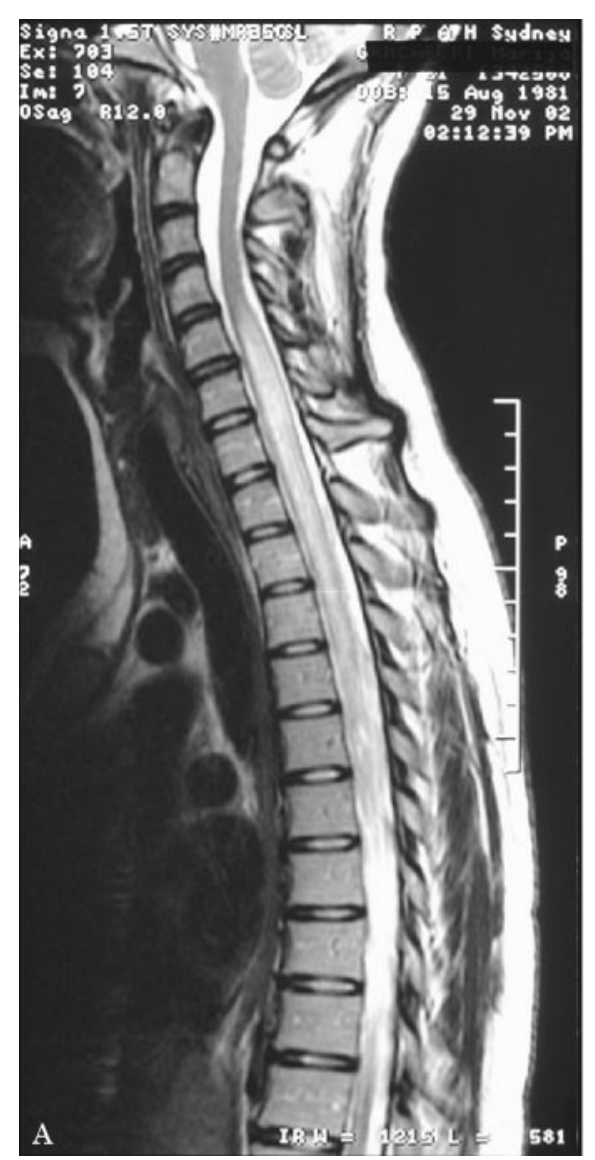

\section{Acute transverse myelitis in SLE}

Arun V. Krishnan, MBBS, Gabor Michael Halmagyi, MD, Sydney, Australia

A 21-year-old woman with a 5-year history of systemic lupus erythematosus (SLE) presented with a 4-hour paraparesis. Examination revealed absent knee and ankle reflexes, extensor plantar responses, and a T4 sensory level. MRI showed cord swelling and high T2 signal from C4/5 to T9/10 (figure, A) and within the

Address correspondence and reprint requests to Prof. G.M. Halmagyi, Department of Neurology, Royal Prince Alfred Hospital, Sydney, NSW 2050, Australia; e-mail: Michael@icn.usyd.edu.au

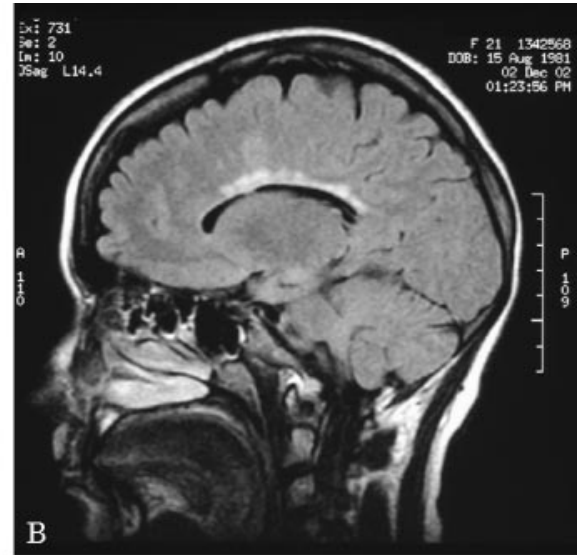

Figure. (A) Sagittal T2-weighted MRI scan of spine shows cord enlargement from C4/5 to T9/10 with high signal change within the cord. There was patchy enhancement noted following contrast administration in the midthoracic region. (B) Sagittal fluid-attenuated inversion recovery brain MRI showing numerous foci of increased signal intensity within the corpus callosum and pericallosal white matter. corpus callosum and pericallosal white matter (figure, B). CSF oligoclonal bands were absent and visual evoked responses were normal. Brain MRI findings in neuropsychiatric lupus can mimic multiple sclerosis. ${ }^{1}$ However, in acute transverse myelitis with lupus there is longitudinal cord involvement, whereas in multiple sclerosis it is often limited to only a few levels. ${ }^{2}$ This patient recovered with IV cyclophosphamide and methylprednisone but soon relapsed.

1. Mok CC, Lau CS, Chan EY, Wong RW. Acute transverse myelopathy in systemic-lupus erythematosus: clinical presentation, treatment and outcome. J Rheumatol 1998;25:467-473.

2. de Seze J, Stojkovic T, Breteau G, et al. Acute myelopathies: clinical, laboratory and outcome profiles in 79 cases. Brain 2001;124:1509-1521. 


\title{
Neurology
}

\author{
Acute transverse myelitis in SLE \\ Arun V. Krishnan and Gabor Michael Halmagyi \\ Neurology 2004;62;2087 \\ DOI 10.1212/01.WNL.0000123089.25458.90
}

This information is current as of June 7, 2004

\section{Updated Information \& Services}

References

Citations

Subspecialty Collections

Permissions \& Licensing

Reprints including high resolution figures, can be found at: http://n.neurology.org/content/62/11/2087.full

This article cites 2 articles, 0 of which you can access for free at: http://n.neurology.org/content/62/11/2087.full\#ref-list-1

This article has been cited by 3 HighWire-hosted articles: http://n.neurology.org/content/62/11/2087.full\#\#otherarticles

This article, along with others on similar topics, appears in the following collection(s):

All Spinal Cord

http://n.neurology.org/cgi/collection/all_spinal_cord

Autoimmune diseases

http://n.neurology.org/cgi/collection/autoimmune_diseases

Lupus

http://n.neurology.org/cgi/collection/lupus

MRI

http://n.neurology.org/cgi/collection/mri

Transverse myelitis

http://n.neurology.org/cgi/collection/transverse_myelitis

Information about reproducing this article in parts (figures,tables) or in its entirety can be found online at:

http://www.neurology.org/about/about_the_journal\#permissions

Information about ordering reprints can be found online:

http://n.neurology.org/subscribers/advertise

Neurology ${ }^{\circledR}$ is the official journal of the American Academy of Neurology. Published continuously since 1951, it is now a weekly with 48 issues per year. Copyright . All rights reserved. Print ISSN: 0028-3878. Online ISSN: 1526-632X.

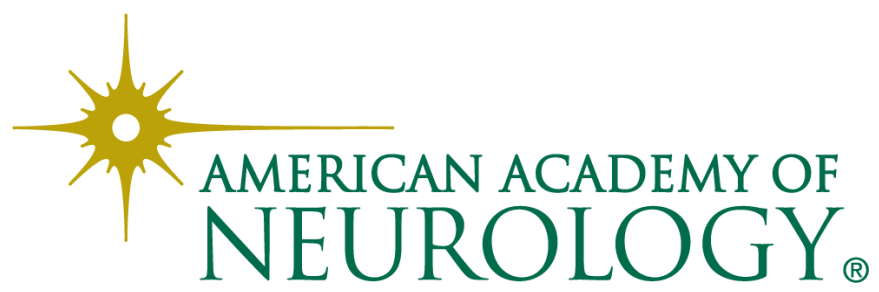

